\title{
TITLE:
}

\section{Magnesium gating of cardiac gap junction channels.}

$\operatorname{AUTHOR}(\mathrm{S})$ :

Matsuda, Hiroyuki; Kurata, Yasutaka; Oka, Chiaki; Matsuoka, Satoshi; Noma, Akinori

\section{CITATION:}

Matsuda, Hiroyuki ... [et al]. Magnesium gating of cardiac gap junction channels.. Progress in biophysics and molecular biology 2010, 103(1): 102-110

ISSUE DATE:

2010-09

URL:

http://hdl.handle.net/2433/128921

\section{RIGHT:}

(C) 2010 Elsevier Ltd; この論文は出版社版でありません。引用の際には 出版社版をご確認ご利用ください。; This is not the published version. Please cite only the published version. 


\section{Magnesium gating of cardiac gap junction channels}

Hiroyuki Matsuda ${ }^{1}$, Yasutaka Kurata ${ }^{2}$, Chiaki Oka ${ }^{1}$, Satoshi Matsuoka ${ }^{1}$, and Akinori Noma ${ }^{1}$

${ }^{1}$ Department of Physiology and Biophysics, Graduate School of Medicine, Kyoto University, Yoshida-konoe, Sakyo-ku, Kyoto 606-8501, Japan

2Department of Physiology, Kanazawa Medical University, Ishikawa 920-0293, Japan

Present address:

Hiroyuki Matsuda; Nano Medicine Merger Education Unit, Graduate School of Medicine, Kyoto University, Yoshida-konoe, Sakyo-ku, Kyoto 606-8501, Japan. Satoshi Matsuoka; Center for Innovation in Immunoregulative Technology and Therapeutics, Graduate School of Medicine, Kyoto University, Yoshida-konoe, Sakyo-ku, Kyoto 606-8501, Japan.

Akinori Noma; College of Life Sciences, Ritsumeikan University, 1-1-1 Noji Higashi, Shiga 525-8577, Japan.

Corresponding Author: Satoshi Matsuoka:

Center for Innovation in Immunoregulative Technology and Therapeutics, Graduate School of Medicine, Kyoto University, Yoshida-konoe, Sakyo-ku, Kyoto 606-8501, Japan.

Tel.: +81-75-753-9507

Fax: +81-75-753-9500

E-mail: smatsuoka@ak.med.kyoto-u.ac.jp 


\section{Abstract}

We aimed to study kinetics of modulation by intracellular $\mathrm{Mg}^{2+}$ of cardiac gap junction $\left(\mathrm{Mg}^{2+}\right.$ gate). Paired myocytes of guinea-pig ventricle were superfused with solutions containing various concentrations of $\mathrm{Mg}^{2+}$. In order to rapidly apply $\mathrm{Mg}^{2+}$ to one aspect of the gap junction, the non-junctional membrane of one of the pair was perforated at nearly the connecting site by pulses of nitrogen laser beam. The gap junction conductance $\left(G_{j}\right)$ was measured by clamping the membrane potential of the other cell using two-electrode voltage clamp method. The laser perforation immediately increased $G_{j}$, followed by slow $G_{j}$ change with time constant of 3.5 sec at $10 \mathrm{mM} \mathrm{Mg}^{2+}$. $\mathrm{Mg}^{2+}$ more than $1.0 \mathrm{mM}$ attenuated dose-dependently the gap junction conductance and lower $\mathrm{Mg}^{2+}(0.6 \mathrm{mM})$ increased $\mathrm{G}_{\mathrm{j}}$ with a Hill coefficient of 3.4 and a half-maximum effective concentration of $0.6 \mathrm{mM}$. The time course of $\mathrm{G}_{\mathrm{j}}$ changes was fitted by single exponential function, and the relationship between the reciprocal of time constant and $\mathrm{Mg}^{2+}$ concentration was almost linear. Based on the experimental data, a mathematical model of $\mathrm{Mg}^{2+}$ gate with one open state and three closed states well reproduced experimental results. One-dimensional cable model of thirty ventricular myocytes connected to the $\mathrm{Mg}^{2+}$ gate model suggested a pivotal role of the $\mathrm{Mg}^{2+}$ gate of gap junction under pathological conditions.

\section{Key Words:}

Gap junction channel, chemical gating, numerical ventricular cell model, arrhythmia, $\mathrm{Mg}^{2+}$ 


\section{Introduction}

Gap junction channels (GJCs) provide a pathway of low electrical resistance between the adjacent cells and play a pivotal role in synchronized contraction of the heart. Conductance of GJCs is regulated by the trans-junctional potential (voltage gate), phosphorylation as well as several intracellular molecules (chemical gate), such as $\mathrm{H}^{+}$and $\mathrm{Ca}^{2+}$ (Bukauskas et al. 2004; Peracchia et al. 2004; Desplantez et al. 2007). Under some circumstances, such as ischemia, GJCs close and cellular communication is uncoupled electrically and metabolically, separating damaged cells from intact cells. Thus, GJCs work as fire shutter.

$\mathrm{Mg}^{2+}$ is one of the intracellular molecules that modulate GJCs. Free intracellular $\mathrm{Mg}^{2+}$ concentration $\left(\left[\mathrm{Mg}^{2+}\right]_{\mathrm{i}}\right)$ is maintained within a narrow range of $0.5-1 \mathrm{mM}$ (Grubbs 2002). Under ischemic conditions, $\left[\mathrm{Mg}^{2+}\right]_{\mathrm{i}}$ increases because of decrease in ATP (Carmeliet 1999; Murphy et al. 1989) that is the major buffer of $\mathrm{Mg}^{2+}$ (Michailova et al. 2001; Grubbs 2002). Intracellular $\mathrm{Mg}^{2+}$ regulates several ion channels in cardiac myocyte (Gusev et al. 2008; Wang et al. 2006; Vemana et al. 2008; Ishihara et al. 2009; Shi et al. 2002). Therefore, $\mathrm{Mg}^{2+}$ may be one of key factors in ischemic arrhythmia like $\mathrm{H}^{+}$and $\mathrm{Ca}^{2+}$ (Swietach et al. 2007). $\mathrm{Mg}^{2+}$ gating of GJCs was first reported in salivary gland cells by Oliveira-Castro and Loewenstein (1971). Noma and Tsuboi (1987) confirmed the $\mathrm{Mg}^{2+}$ effect and steady state $\mathrm{Mg}^{2+}$ dependence of GJCs conductance was studied in adult guinea-pig ventricular myocytes using 'open cell' method. However, no significant effect of $\mathrm{Mg}^{2+}$ was observed on the GJCs conductance of cultured neonatal ventricular myocytes of rat (Firek et al. 1995). No further systemic studies on the $\mathrm{Mg}^{2+}$ gating of GJCs have been carried out.

In this study, we used 'laser beam perforation' method for rapidly applying $\left[\mathrm{Mg}^{2+}\right]_{\mathrm{i}}$ to GJCs and two-electrode voltage clamp method for accurately controlling membrane voltage. A numerical model was constructed based on the gating kinetics.

\section{Material and Methods}

\subsection{Isolation of guinea-pig ventricular myocytes}

Paired ventricular cells were prepared according to previous studies (Kameyama. 1983; Mitra et al. 1985). Briefly, female guinea-pigs (4-weeks-old) were 
anaesthetized by an intraperitoneal injection of sodium pentobarbital $(50 \mathrm{mg} / \mathrm{kg})$. The heart was quickly excised after the open of thoracic cavity, and suspended on a Langendorff perfusion apparatus. The flow rate was approximately $10 \mathrm{~mL} \mathrm{~min}^{-1}$. The isolated heart was perfused initially with a control Tyrode solution for 10 to 15 minutes, secondary with a $\mathrm{Ca}^{2+-}$ free Tyrode solution for 5 minutes, and thirdly with a $\mathrm{Ca}^{2+}$-free Tyrode solution containing collagenase (50 U. $\mathrm{ml}^{-1}$, Warthingtone type I) for 20 minutes. Finally, the heart was perfused with a Kraftbrühe (KB) medium for 10 minutes. These procedures were performed at $37^{\circ} \mathrm{C}$. Myocytes were gently dispersed by mechanical agitation. Isolated cells including paired cells were kept in the $\mathrm{KB}$ medium at $4^{\circ} \mathrm{C}$ for at least 1 hour before use in experiments.

\subsection{Whole- cell voltage clamp using double giga-sealed patch electrodes}

Isolated cells were transferred to a chamber mounted on an inverted microscope (Axiovert135; Zeiss, Germany). Paired cells with approximately same size were used for experiments. To accurately control membrane potential, the two-electrode voltage clamp (TEVC) method was applied (Axoclamp 2B amplifier; Axon instruments, USA) with the essentially same protocol as Noma and Tsuboi (1987). Briefly, two patch pipettes filled with an internal solution were prepared (electrical resistance $=2 \sim 5 \mathrm{M} \Omega$ ) on separate micro manipulators. After the two pipettes were attached on the cell surface of one of the paired cells (cell 1), giga ohm seal and whole-cell configuration were established by applying negative pressure of $20-50 \mathrm{~cm}$ $\mathrm{H}_{2} \mathrm{O}$. A schematic diagram of voltage clamp circuit was shown in Fig.1A.

\subsection{Experimental protocol}

After replacing the control Tyrode solution with a $\mathrm{Cs}^{+}-$rich intracellular solution containing a given concentration of $\mathrm{Mg}^{2+}$, the membrane of the paired cell (cell 2) close to cell 1 was instantaneously perforated by applying pulses of nitrogen laser (VSL-337ND; Laser Science, USA). The distance between the cell connection site and the holes were within about $15 \mu \mathrm{m}$. Usually about 10 holes were made within 1 sec. At the end of experiments, the cells were superfused with a solution containing $0.1 \mathrm{mM} \mathrm{Mg}^{2+}$ to normalize input conductance.

A series of test potential to $\pm 5 \mathrm{mV}$ from a holding potential of $0 \mathrm{mV}$ was applied every $500 \mathrm{~ms}$ (Fig. 1B).This voltage protocol is unlikely to affect the voltage gating of GJCs because conductance of homomeric-homotypic $\mathrm{Cx} 43$ channels, which is a 
dominant isoform of connexins in ventricular myocardium, is almost constant at voltage from -30 to $30 \mathrm{mV}$ (González et al. 2007). The equivalent electrical circuits before and after the laser perforation are illustrated in Fig. 1C. The GJCs conductance $\left(\mathrm{G}_{\mathrm{j}}\right)$ was obtained on the following assumptions as previous studies (Noma and Tsuboi 1987; Sugiura et al. 1990; Toyama et al. 1994).

Before the laser perforation, input conductance $\left(\mathrm{G}_{\mathrm{i}}\right)$ is expressed as follows

$$
\mathrm{G}_{\mathrm{i}}=\mathrm{G}_{\mathrm{m}, 1}+\mathrm{G}_{\mathrm{j}} \cdot \mathrm{G}_{\mathrm{m}, 2} /\left(\mathrm{G}_{\mathrm{j}}+\mathrm{G}_{\mathrm{m}, 2}\right),
$$

where $G_{m, 1}$ and $G_{m, 2}$ are non-junctional membrane conductance of cell 1 and cell 2 , respectively. If $G_{m, 1}$ is equal to $G_{m, 2}$ and $G_{j}$ is much greater than $G_{m, 1}$ and $G_{m, 2}\left(G_{j}\right.$ $\left.>\mathrm{G}_{\mathrm{m}}\right), \mathrm{G}_{\mathrm{i}}$ will be simplified.

$$
\mathrm{G}_{\mathrm{i}}=2 \cdot \mathrm{G}_{\mathrm{m}}, \mathrm{G}_{\mathrm{m}}=\mathrm{G}_{\mathrm{m}, 1}=\mathrm{G}_{\mathrm{m}, 2}
$$

After the perforation, $G_{m, 2}$ could be ignored.

$$
\mathrm{G}_{\mathrm{i}}=\mathrm{G}_{\mathrm{m}, 1}+\mathrm{G}_{\mathrm{j}} \cdot \mathrm{G}_{\mathrm{s}} /\left(\mathrm{G}_{\mathrm{j}}+\mathrm{G}_{\mathrm{s}}\right) \text {, }
$$

where $\mathrm{G}_{\mathrm{s}}$ is the conductance through the holes made in cell 2. If $\mathrm{G}_{\mathrm{s}}$ is much larger than $G_{j}, G_{j}$ will be obtained with following equation

$$
\mathrm{G}_{\mathrm{i}}=\mathrm{G}_{\mathrm{m}}+\mathrm{G}_{\mathrm{j}}, \mathrm{G}_{\mathrm{m}}=\mathrm{G}_{\mathrm{m}, 1}
$$

$\mathrm{G}_{\mathrm{j}}$ can be calculated with equations (1) and (2).

In this study, non-junctional membrane conductance was suppressed by a $\mathrm{K}^{+}$free, $\mathrm{Ca}^{2+}$ free and low $\mathrm{Cl}^{-}$solution. Contribution of the $\mathrm{H}^{+}$and $\mathrm{Ca}^{2+}$ gatings of GJC might be negligible because the $\mathrm{Ca}^{2+}$ and $\mathrm{H}^{+}$was strongly buffered with $5 \mathrm{mM}$ EGTA and HEPES (see below).

\subsection{Solutions}

The composition of Tyrode solution was (in mM): $140 \mathrm{NaCl}, 5.4 \mathrm{KCl}, 0.5 \mathrm{MgCl}_{2}$, $1.8 \mathrm{CaCl}_{2}, 0.33 \mathrm{NaH}_{2} \mathrm{PO}_{4}, 5.5$ glucose and 5 Hepes; $\mathrm{pH}$ was adjusted to 7.4 with $\mathrm{NaOH}$. KB solution contained (in mM): $90 \mathrm{KOH}, 30 \mathrm{KCl}, 10 \mathrm{KH}_{2} \mathrm{PO}_{4}, 70 \mathrm{~L}$-glutamic acid, 20 taurine, 10 HEPES, 10 D-glucose, 0.5 EGTA, $1 \mathrm{MgCl}_{2}$; $\mathrm{pH}$ was adjusted to 7.4 with $\mathrm{KOH}$. The internal solution in the patch electrode contained (in mM) 110 CsOH, 20 TEACl, 5 Na 2 ATP, 5 HEPES, 5 EGTA, $5 \mathrm{Na}_{2}$ CRP, 110 Aspartic acid, 3 $\mathrm{MgCl}_{2}(\mathrm{pMg}=4) ; \mathrm{pH}$ was adjusted to 7.4 with $\mathrm{CsOH}$. The composition of the test solution was the same as the internal solution, except for $\mathrm{MgCl}_{2}$. Free $\mathrm{Mg}^{2+}$ concentration (0.1-10 $\mathrm{mM})$ was calculated according to a software 'WinMaxC' (http://www.stanford.edu/ cpatton/maxc.html). 


\subsection{Model construction}

A mathematical model of gap junction was constructed using Delphi 2009 (Embarcadero technologies, USA) and differential equations were solved with fourth-order Runge-Kutta method.

Propagation of action potential was examined with a one-dimensional (1-D) cable model, which consisted of thirty ventricular cell models connected to gap junctions. The guinea-pig ventricular cell model published by kuzumoto et al. (2008) was used, where cell volume was fixed to a constant value for simplicity. Open probability $\left(\mathrm{P}_{\mathrm{Open}, \mathrm{i}}\right)$ of a gap junction connecting cell (i) and cell (i+1) is expressed as

$$
\begin{aligned}
& P_{\text {Open, } \mathrm{i}}=\mathrm{P}_{\mathrm{i}} \cdot \mathrm{P}_{\mathrm{i}+1} \\
& \mathrm{G}_{\mathrm{j}, \mathrm{i}}=\mathrm{N} \cdot \mathrm{g}_{\mathrm{j}} \cdot \mathrm{P}_{\text {Open, } \mathrm{i}}
\end{aligned}
$$

where $\mathrm{P}_{\mathrm{i}}$ and $\mathrm{P}_{\mathrm{i}+1}$ are the open probabilities of the hemichannels facing $\left[\mathrm{Mg}^{2+}\right]_{i}$ of cell (i) and cell ( $\mathrm{i}+1)$, respectively. $\mathrm{N}$ is the number of channels, $\mathrm{g}_{\mathrm{j}}$ the maximal conductance of the unitary channel. Since the half-life of $\mathrm{Cx} 43$ was hours order in adult heart (Beardslee et al. 1998), and cation such as $\mathrm{H}^{+}$or $\mathrm{Ca}^{2+}$ do not affect maximal conductance (Brink et al. 1989; Veenstra et al. 1988), we assumed that $\mathrm{N}$ and $g_{j}$ were constant and set $\mathrm{N} \cdot \mathrm{g}_{\mathrm{j}}$ to $9000 \mathrm{nS}$ to yield normal conductance velocity (450 - 700 mm/sec, Eloff et al. 2003; Harada et al. 2008; Rossi et al. 2008; Akar et al. 2007) at physiological $\left[\mathrm{Mg}^{2+}\right]_{\mathrm{i}}$.

The membrane potential of cell $(\mathrm{i})\left(V_{\mathrm{m}, i}\right)$ in a 1 -D cable model was calculated as follows.

$$
\begin{aligned}
& d V_{m, i} / d t=-\left(I_{t o t, i}+I_{j, i}-I_{j, i-1}\right) / C_{m} \\
& I_{j, i}=G_{j, i} \cdot\left(V_{m, i+1}-V_{m, i}\right)
\end{aligned}
$$

Here $\mathrm{C}_{\mathrm{m}}$ and $\mathrm{I}_{\text {tot, }}$ are membrane capacitance and total membrane current of cell (i), respectively. $\mathrm{I}_{\mathrm{j}, \mathrm{i}}$ and $\mathrm{G}_{\mathrm{j}, \mathrm{i}}$ are the current and conductance of a gap junction connecting cell (i) and cell cell (i+1), respectively. For simplicity, the electrical resistances of the intra- and extracellular medium were neglected. The model was excited at $2.5 \mathrm{~Hz}$ by applying to cell (i) a stimulus pulse, which was $2.0 \mathrm{~ms}$ in duration and $20 \mathrm{nA}$ in amplitude. Time step was $0.005 \mathrm{msec}$.

The conduction velocity (CV) between cell (i) and cell (i+1) was calculated by a following equation

$$
\mathrm{CV}=\mathrm{L} /\left(\mathrm{t}_{0, \mathrm{i}+1}-\mathrm{t}_{0, \mathrm{i}}\right)
$$

Here the cell length $(\mathrm{L})$ is set at $100 \mu \mathrm{m}$, and $\mathrm{t}_{0, i}$ represents the time of AP rising over $0 \mathrm{mV}$ in cell (i). In simulation, only $\left[\mathrm{Mg}^{2+}\right]_{i}$ which affects gap junction was changed when changing the concentration, to clarify the effect of $\left[\mathrm{Mg}^{2+}\right]_{\text {i }}$ on gap junction. 


\subsection{Data analysis and equipments}

Model equations were fitted to data by a non-linear, least squares method using Sigmaplot 10.0 (Systat Software Inc, CA, USA).

\section{Results}

\section{1. $\mathrm{Mg}^{2+}$ dependence of GJCs conductance}

Fig. 2 shows a typical experimental result. Representative current traces and time course of $\mathrm{G}_{j}$ are shown at $\mathrm{A}$ and $\mathrm{B}$, respectively. A pair of myocytes was superfused with a solution containing $10 \mathrm{mM} \mathrm{Mg}{ }^{2+}$. Laser perforation induced a rapid jump-up of $G_{j}(b)$, followed by slower decrease (c). The $G_{j}$ immediately after the laser perforation reflects $G_{j}$ at physiological condition. The following decrease in $G_{j}$ was probably related to closing of the hemichannels of cell 2 by $10 \mathrm{mM} \mathrm{Mg}^{2+}$, because changing the perfusion solution to that containing $0.1 \mathrm{mM} \mathrm{Mg}^{2+}$ (slow perfusion) increased $\mathrm{G}_{\mathrm{j}}$ by about 500 times. Thus, $\mathrm{G}_{\mathrm{j}}$ was clearly dependent on $\left[\mathrm{Mg}^{2+}\right]_{\mathrm{i}}$.

\subsection{Time course of $\mathrm{G}_{j}$ modulation by $\mathbf{M g}^{2+}$}

In the majority of experiments, no significant delay was observed in the $\mathrm{G}_{\mathrm{j}}$ change after the laser perforation. However, if the laser holes were made away from the site of cell connection, significant delay was observed. In Fig.3, laser beam were applied at 11,18 and $48 \mu \mathrm{m}$ from the junction. At $48 \mu \mathrm{m}$, delay of about $5 \mathrm{sec}$ was observed and decay speed was markedly slower than the ones at 11 and $18 \mu \mathrm{m}$. The delay was presumably caused by the intracellular diffusion of $\mathrm{Mg}^{2+}$. The $\mathrm{G}_{\mathrm{j}}$ decay without delay suggested that $\mathrm{Mg}^{2+}$ gate does not include multiple open states.

The $\mathrm{G}_{\mathrm{j}}$ changes after the laser perforation could be fitted by single exponential function as shown in Fig.4. When a solution containing lower $\left[\mathrm{Mg}^{2+}\right]_{\mathrm{i}}$ was used $(0.6$ $\mathrm{mM}), \mathrm{G}_{\mathrm{j}}$ exponentially increased after the laser perforation. This finding is consistent with data in Fig.2 and further confirms a view that $\mathrm{G}_{\mathrm{j}}$ depends on $\left[\mathrm{Mg}^{2+}\right]_{\mathrm{i}}$.

\subsection{Dependencies of $\tau^{-1}$ and steady-state $\mathrm{G}_{j}$ on $\mathbf{M g}^{2+}$}

Steady state dependence of $\mathrm{G}_{\mathrm{j}}$ on $\left[\mathrm{Mg}^{2+}\right]_{\mathrm{i}}$ was fitted to a Hill equation with a Hill coefficient of 3.4 and a half-maximum effective concentration (EC50) of $0.6 \mathrm{mM}$ (Fig.4C). The value of EC50 was smaller than the one reported by Noma and Tsuboi (1987), but the Hill coefficient was similar. High cooperativity of $\mathrm{Mg}^{2+}$ suggested that $\mathrm{Mg}^{2+}$ more than 3 binds to the hemichannel. Fig.4D shows a relationship 
between $\left[\mathrm{Mg}^{2+}\right]_{i}$ and reciprocal time constant of the $\mathrm{G}_{\mathrm{j}}$ change $\left(\tau^{-1}\right)$. A linear relationship was found.

\subsection{Construction of $\mathrm{Mg}^{2+}$ gate model}

We constructed a $\mathrm{Mg}^{2+}$ gating model of gap junction as follows. If the $\mathrm{Mg}^{2+}$ gate of the hemichannel is followed by a simple two-state model including one open $(\mathrm{O})$ and one closed state ( $\mathrm{C}, \mathrm{C}=1-\mathrm{O}$ ) (Fig.5A), time derivative (dO/dt), steady state open probability $\left(\mathrm{P}_{\text {open_ss }}\right)$ and rate constant $\left(=\tau^{-1}\right)$ are given as follows:

$$
\begin{aligned}
& \mathrm{dO} / \mathrm{dt}=-\alpha \cdot\left[\mathrm{Mg}^{2+}\right]^{\mathrm{n}} \cdot \mathrm{O}+B \cdot \mathrm{C}=-\left(\alpha \cdot\left[\mathrm{Mg}^{2+}\right] \mathrm{n}+B\right) \cdot \mathrm{O}+B \\
& \mathrm{P}_{\text {Open_ss }}=B /\left(\alpha \cdot\left[\mathrm{Mg}^{2+}\right] \mathrm{n}+B\right) \\
& \tau^{-1}=\alpha \cdot\left[\mathrm{Mg}^{2+}\right]^{\mathrm{n}}+B,
\end{aligned}
$$

where $a, B$ and $n$ represent forward rate constant, backward one and a number of $\mathrm{Mg}^{2+}$ molecule, respectively. The Hill coefficient obtained in Fig $4 \mathrm{C}$ indicated that $\mathrm{n}$ is more than 3. However, since $\tau^{-1}$ depends on $\left[\mathrm{Mg}^{2+}\right] \mathrm{n}$ in this model, the linear relationship between $\tau^{-1}$ and $\left[\mathrm{Mg}^{2+}\right]$ obtained in Fig. 4D could not be reproduced. If we assume that $3 \mathrm{Mg}^{2+}$ bind to the hemichannel, four states may exist. Since one single exponential function fit well to the time course of $\mathrm{Mg}^{2+}$ gate, transition between open and close states may be slow (rate limiting) and other steps could be assumed as instantaneous reaction. The possible combination is listed in Fig.5B.

Differential equation of the open probability can be described as follows.

$$
\mathrm{dO}_{\mathrm{T}} / \mathrm{dt}=-\mathrm{Q} \cdot \mathrm{O}_{\mathrm{T}}+\mathrm{R},
$$

where $\mathrm{O}_{\mathrm{T}}$ is a summation of all open states, $\mathrm{Q}$ rate constant $\left(=\tau^{-1}\right), \mathrm{R}$ a function of $\alpha_{1}, \alpha_{2}, \alpha_{3}, B_{1}, B_{2}, B_{3}$, and $\left[\mathrm{Mg}^{2+}\right]$.

If $1^{\text {st }}$ step is rate limiting (Fig.5B1),

$$
\mathrm{Q}=\mathrm{\alpha}_{1}\left[\mathrm{Mg}^{2+}\right]+\mathrm{B}_{1} /\left(1+\left(\mathrm{\alpha}_{2} / \mathrm{B}_{2}\right)\left[\mathrm{Mg}^{2+}\right]\right)^{2}
$$

If $2^{\text {nd }}$ step is rate limiting (Fig.5B2),

$$
\left.\mathrm{Q}=\mathrm{\alpha}_{2}\left[\mathrm{Mg}^{2+}\right] /\left(\left(\mathrm{\alpha}_{1} / \mathrm{B}_{1}\right)\left[\mathrm{Mg}^{2+}\right]\right)^{-1}+1\right)+\mathrm{B}_{2} /\left(1+\left(\mathrm{\alpha}_{3} / \mathrm{B}_{3}\right)\left[\mathrm{Mg}^{2+}\right]\right.
$$

If $3^{\text {rd }}$ step is rate limiting (Fig.5B3),

$$
\mathrm{Q}=\mathrm{\alpha}_{3}\left[\mathrm{Mg}^{2+}\right] /\left(1+\left(\left(\mathrm{\alpha}_{2} / \mathrm{B}_{2}\right)\left[\mathrm{Mg}^{2+}\right]\right)^{-1}+\left(B_{1} B_{2} / \mathrm{\alpha}_{1} \mathrm{\alpha}_{2}\right)[\mathrm{Mg}]^{-2}\right)+B_{3}
$$

Only equation (3) has a term which depends linearly on $\left[\mathrm{Mg}^{2+}\right]$. The linear relationship between $\tau^{-1}$ and $\left[\mathrm{Mg}^{2+}\right]$ could not be reproduced with other models. Furthermore, The $\mathrm{G}_{\mathrm{j}}$ decay without delay (Fig. 3) also supports the model with one open state. Therefore, we adopted the model of Fig.5B1.

To further simplify this model, we assumed forward $\left(\mathrm{k}_{\mathrm{f}}\right)$ and backward $\left(\mathrm{k}_{\mathrm{b}}\right)$ rate constants of single $\mathrm{Mg}^{2+}$ binding within closed state. Thus, $\mathrm{K}_{\mathrm{d}}=\mathrm{k}_{\mathrm{f}} / \mathrm{k}_{\mathrm{b}}, \mathrm{a}_{2}=2 \mathrm{k}_{\mathrm{f}}, \mathrm{B}_{2}=\mathrm{k}_{\mathrm{b}}$, $\alpha_{3}=k_{\mathrm{f}}, B_{3}=2 \mathrm{k}_{\mathrm{b}}$. The differential equation, rate constant and steady state open probability of model Fig.5B1 are described as follows. 


$$
\begin{aligned}
& \mathrm{d}[\mathrm{O}] / \mathrm{dt}=-\left\{\mathrm{a}_{1}\left[\mathrm{Mg}^{2+}\right]+B_{1} /\left(1+\mathrm{K}_{\mathrm{d}}\left[\mathrm{Mg}^{2+}\right]\right)^{2}\right\}[\mathrm{O}]_{\mathrm{T}}+B_{1} /\left(\left(\mathrm{a}_{1}\left[\mathrm{Mg}^{2+}\right]\left(1+\mathrm{K}_{\mathrm{d}}\left[\mathrm{Mg}^{2+}\right]\right)^{2}\right)+B_{1}\right) \\
& \mathrm{Q}=\mathrm{a}_{1}\left[\mathrm{Mg}^{2+}\right]+B_{1} /\left(1+\mathrm{K}_{\mathrm{d}}\left[\mathrm{Mg}^{2+}\right]\right)^{2} \\
& \mathrm{P}_{\text {open_ss }}=B_{1} /\left(\left(\mathrm{a}_{1}\left[\mathrm{Mg}^{2+}\right]\left(1+\mathrm{K}_{\mathrm{d}}\left[\mathrm{Mg}^{2+}\right]\right)^{2}\right)+B_{1}\right)
\end{aligned}
$$

Parameters, $\alpha_{1}, B_{1}$ and $K_{d}$ were determined by fitting the experimental data to equations (4) and (5) (Fig 6A and B), where $\alpha_{1}=0.028 \mathrm{~S}^{-1} \mathrm{mM}^{-1}, B_{1}=0.227 \mathrm{~S}^{-1}$ and $\mathrm{K}_{d}=$ $0.2372 \mathrm{mM}^{-2}$, respectively. To simulate the experiments, initial $\left[\mathrm{Mg}^{2+}\right]_{\mathrm{i}}$ just after the laser perforation was estimated with the relationship between $\left[\mathrm{Mg}^{2+}\right]_{i}$ and $\mathrm{G}_{j}$ in $\mathrm{A}$; $1.0 \mathrm{mM}$ in $\mathrm{C}$ and $0.95 \mathrm{mM}$ in $\mathrm{D}$. $\mathrm{Mg}^{2+}$ was changed from the initial values to $10 \mathrm{mM}$ (C) and $0.6 \mathrm{mM}$ (D) in simulation. The model well reproduced the time course of $\mathrm{Mg}^{2+}$ gating.

Propagation of action potential at various $\left[\mathrm{Mg}^{2+}\right]_{\mathrm{i}}$ was examined with a model of tandemly-arrayed ventricular cells (Fig. 7A). Conductance velocity was sharply dependent on $\left[\mathrm{Mg}^{2+}\right]_{i}$. At the physiological range of $\left[\mathrm{Mg}^{2+}\right]_{\mathrm{i}}$ in cardiac cells $(0.5-1$ $\mathrm{mM}$ ), conductance velocity was $645-224 \mathrm{~mm} / \mathrm{sec}$ (Fig. 7B). These values are close to experimental data (450 mm/sec (Akar et al. 2007), $472 \mathrm{~mm} / \mathrm{sec}$ (Eloff et al. 2003), $600 \mathrm{~mm} / \mathrm{sec}$ (Harada et al. 2008) and $690 \mathrm{~mm} / \mathrm{sec}$ (Rossi et al. 2008)). Action potentials of the thirty cells at $0.1,0.7$, and $2.0 \mathrm{mM}\left[\mathrm{Mg}^{2+}\right]_{\mathrm{i}}$ are demonstrated in Fig. 7C. Marked conduction delay were observed at $\left[\mathrm{Mg}^{2+}\right]_{\mathrm{i}}$ more than $1.4 \mathrm{mM}$. Action potential did not propagate to second cell at $\left[\mathrm{Mg}^{2+}\right]_{\mathrm{i}}$ more that $2.8 \mathrm{mM}$.

The time course of action potential modulation by $\mathrm{Mg}^{2+}$ was studied in Fig. 8, Control $\left[\mathrm{Mg}^{2+}\right]_{\mathrm{i}}$ of all the cells was $0.7 \mathrm{mM}$. At time of $4.0 \mathrm{sec},\left[\mathrm{Mg}^{2+}\right]_{\mathrm{i}}$ of cell 11 to 30 was increased to $2.6 \mathrm{mM}$. The open probability of cell 11 to 30 decreased over several tens of seconds (Fig. 8A). Action potential propagation remarkably slowed at cell 11 to 30 and two-to one block appeared (Fig. 8B).

\section{Discussion}

\subsection{Measurements of GJCs conductance with laser perforation technique}

To study kinetics of chemical gate of GJCs in native ventricular cells, fast application of agents to GJCs is prerequisite. Although several methods have been developed (Harris et al. 2001), all the methods have limitations for applying to intact ventricular cells. Noma and Tsuboi (1987) developed 'open-cell' method, in which the non-junctional membrane of one of the paired cells was mechanically ruptured with a glass pipette to allow agents to reach one aspect of the junction. 
However, diffusion delay was marked (> several tens of seconds), so that accurate rate constants of chemical gate could not be obtained. In this study, we used laser beam to make holes near the GJCs of paired cells. The input conductance immediately increased upon applying laser beam (Fig.2) and no marked diffusion delay was observed (Fig.3). Therefore, this new method is suitable for studying kinetics of the chemical gate in native ventricular cells.

\subsection{What is the mechanism of $\mathrm{Mg}^{2+}$ action on GJCs?}

Direct gating of connexin channels by ligands is of key importance in intercellular signaling. However, it is not clear whether the cation gate is direct or indirect reaction to GJCs (Dhein. 2004). Although it is suggested that the $\mathrm{Ca}^{2+}$ effect on GJCs is mediated by an intermediate component such as calmodulin (Lurtz et al. 2007), there is no information about $\mathrm{Mg}^{2+}$ gating mechanism of gap junction channel. Mubagwa et al. (2007) discussed the mechanistic patterns of intracellular $\mathrm{Mg}^{2+}$ action on several cation channels; namely direct binding, allosteric effects, modulation via action on enzymes or $\mathrm{G}$ proteins, interaction with surface charges, interaction with membrane phospholipids, and others. In this paper we assumed that $\mathrm{Mg}^{2+}$ directly binds to GJCs. However, we could not rule out the possibility that the effect was mediated by other molecules. Sugiura et al. (1990) reported that gap junction conductance was increased by ATP, presumably by Mg-ATP, with Hill coefficient of 2.6 and $\mathrm{EC}_{50}$ of $0.68 \mathrm{mM}$. However, in our experiment, total ATP concentration was constant ( $5 \mathrm{mM}$ ) and calculated $\mathrm{Mg}$-ATP concentration was almost similar level among the test solutions; $2.86 \mathrm{mM}$ at the $0.1 \mathrm{mM} \mathrm{Mg}^{2+}$ solution and $4.95 \mathrm{mM}$ at the $10 \mathrm{mM} \mathrm{Mg}{ }^{2+}$ solution. Therefore, the $\mathrm{Mg}^{2+}$ effect observed in this study is unlikely to be mediated by ATP or Mg-ATP.

\subsection{Physiological significance of the $\mathrm{Mg}^{2+}$ gating}

Referring to cardiovascular disease, $\left[\mathrm{Mg}^{2+}\right]_{\mathrm{i}}$ increases in acute myocardial ischemia and decreases in heart failure. Murphy et al. (1989) demonstrated that $\left[\mathrm{Mg}^{2+}\right]_{\mathrm{i}}$ increases from 0.85 to $2.1 \mathrm{mM}$ during 10 to $15 \mathrm{~min}$ of ischemia. Our model suggested significant effects of $\left[\mathrm{Mg}^{2+}\right]_{\mathrm{i}}$ rise from 0.85 to $2.1 \mathrm{mM}$ on gap junction function. Namely, Popen of gap junction decreased to $1.5 \%$ of control $(0.097$ to $0.0015)$ and conduction velocity to $6.9 \%$ of control (281.7 to $19.5 \mathrm{~mm} / \mathrm{s})$. Furthermore, two-to-one block was induced at $2.6 \mathrm{mM}\left[\mathrm{Mg}^{2+}\right]_{\mathrm{i}}$. Therefore, the increase in $\left[\mathrm{Mg}^{2+}\right]_{\mathrm{i}}$ observed in cardiac ischemia may significantly affect ventricular conductance. Haigney et al. (1998) showed that $\left[\mathrm{Mg}^{2+}\right]_{\mathrm{i}}$ decreased from 1.06 to 0.49 
$\mathrm{mM}$ in the dog failing heart caused by rapid pacing. A moderate effect of the fall in $\left[\mathrm{Mg}^{2+}\right]_{\mathrm{i}}$ on gap junction was suggested in our simulation. The change in $\left[\mathrm{Mg}^{2+}\right]_{\mathrm{i}}$ increases the open probability by 7.5 times (0.053 to 0.39 ) and conduction velocity by 2.9 times $\left(224.7\right.$ to $645 \mathrm{~mm} / \mathrm{s}$ ). In real heart, however, $\mathrm{H}^{+}$and $\mathrm{Ca}^{2+}$ may also modulate gap junction function (Bukauskas et al. 2004; Peracchia et al. 2004; Desplantez et al. 2007). Closing of gap junction under the ischemic condition would be further accelerated by the rise of $\mathrm{H}^{+}$and $\mathrm{Ca}^{2+}$.

Recently, complicated patterns of reentrant arrhythmia have been demonstrated in computer simulations, where numerical models of myocyte are connected by gap junctions as resistance factor. In most simulation studies, however, the gap junction conductance was regarded as constant. We previously constructed a mathematical model of the $\mathrm{Ca}^{2+}$ gating of GJCs (Oka et al. 2006). Conduction velocity was clearly dependent on cytoplasmic $\mathrm{Ca}^{2+}$ concentration and remarkable decrease in conduction velocity was induced under a $\mathrm{Ca}^{2+-}$ overloaded condition. Thus, chemical gating by $\mathrm{H}^{+}$and $\mathrm{Ca}^{2+}$ and $\mathrm{Mg}^{2+}$ has to be considered in the model simulation to get deeper insight into the mechanisms underlying arrhythmia under pathological conditions.

\subsection{Clinical use of $\mathrm{Mg}^{2+}$}

Intravenous administration of $\mathrm{Mg}^{2+}$ has been reported to be useful in preventing some kinds of arrhythmias such as rapid atrial fibrillation and torsades de pointes (TdP) (Onalan et al. 2007; Hoshino et al. 2006). The main antiarrhythmic mechanism of $\mathrm{Mg}^{2+}$ has been considered to be a $\mathrm{Ca}^{2+}$ antagonistic effect (Gomez 1998). The effective antiarrhythmic concentration of free $\mathrm{Mg}^{2+}$ is $0.5 \sim 1.0 \mathrm{mM} ; 1.1 \sim$ $1.2 \mathrm{mM}$ (Hoshino et al. 2006) and $0.54 \mathrm{mM}$ (Kasaoka et al. 1996)). On the other hand, $\mathrm{Mg}^{2+}$ at high concentration is known to cause several side effects such as bradycardia or atrioventricular block. Symptoms of $\mathrm{Mg}^{2+}$ toxicity were reported to develop at its serum concentration more than $1.7 \sim 2.6 \mathrm{mM}$ (Musso 2009). Considering that free $\mathrm{Mg}^{2+}$ is about half of total serum $\mathrm{Mg}^{2+}$ concentration and that intracellular free $\mathrm{Mg}^{2+}$ is about the same as extracellular free $\mathrm{Mg}^{2+}$ concentration, high dose application of $\mathrm{Mg}^{2+}$ may cause blockade of GJCs in clinical situation. 


\section{Conclusions}

We studied kinetics of $\mathrm{Mg}^{2+}$ gate of gap junction in intact guinea-pig ventricular cells and reconstructed mathematical models. It was suggested that the rise of $\left[\mathrm{Mg}^{2+}\right]_{\mathrm{i}}$ remarkably modulates conductance of gap junction.

\section{Acknowledgements}

This study was supported by the leading project for biosimulation (H.M., C.O., S.M. and A.N.) and a grant-in-aid for scientific research from the ministry education, culture, sports, and technology of Japan (H.M., S.M.).

\section{References}

Akar, F.G., Nass, R.D., Hahn, S., Cingolani, E., Shah, M., Hesketh, G.G., DiSilvestre, D., Tunin, R.S., Kass, D.A., Tomaselli, G.F. 2007. Dynamic changes in conduction velocity and gap junction properties during development of pacing-induced heart failure. Am. J. Physiol. Heart. Circ. Physiol. 293, H1223-30.

Beardslee, M.A., Laing, J.G., Beyer, E.C., Saffitz, J.E., 1998. Rapid turnover of Connexin 43 in the adult rat heart. Circ. Res. 83, 629-35.

Brink, P.R., Fan, S.F., 1989. Patch clamp recordings from membranes which contain gap junction channels. Biophys. J. 56, 579-93.

Bukauskas, F.F., Verselis, V.K., 2004. Gap junction channel gating. Biochimica. Biophysica. Acta. 1662, 42-60.

Carmeliet, E., 1999. Cardiac ionic currents and acute ischemia: from channels to arrhythmia. Physiol. Rev. 79, 917-1017.

Desplantez, T., Dupont, E., Severs, N.J., Weingart, R., 2007. Gap junction channels and cardiac impulse propagation. J. Membr. Biol. 218,13-28.

Dhein, S., 2004. Pharmacology of gap junctions in the cardiovascular system. Cardiovasc. Res. 62, 287-98. 
Eloff, BC., Gilat, E., Wan, X., Rosenbaum, D.S., 2003. Pharmacological modulation of cardiac gap junctions to enhance cardiac conduction: evidence supporting a novel target for antiarrhythmic therapy. Circulation. 108, 3157-63.

Firek, L., Weingart, R., 1995. Modification of gap junction conductance by divalent cations and protons in neonatal rat heart cells. J. Mol. Cell. Cardiol. 27, 1633-43.

Gomez M.N., 1998. Magnesium and Cardiovascular Disease. Anesthesiology. 89, $222-40$.

González, D., Gómez-Hernández, J.M., Barrio, L.C., 2007. Molecular basis of voltage dependence of connexin channels: an integrative appraisal. Prog. Biophys. Mol. Biol. 94, 66-106.

Grubbs, R.D., 2002. Intracellular magnesium and magnesium buffering. Biometals. $15,251-9$.

Gusev, K., Niggli, E., 2008. Modulation of the Local SR Ca ${ }^{2+}$ Release by Intracellular $\mathrm{Mg}^{2+}$ in Cardiac Myocytes. J. Gen. Physiol. 132, 721 - 30.

Haigney, M.C., Wei, S., Kaab, S., Griffiths, E., Berger, R., Tunin, R., Kass, D., Fisher, W.G., Silver, B., Silverman, H. 1998. Loss of Cardiac Magnesium in Experimental Heart Failure Prolongs and Destabilizes Repolarization in Dogs. J. Am. Coll. Cardiol. 31, 701-6.

Harada, M., Honjo, H., Yamazaki, M., Nakagawa, H., Ishiguro, Y.S., Okuno, Y., Ashihara, T., Sakuma, I., Kamiya, K., Kodama, I. 2008. Moderate hypothermia increases the chance of spiral wave collision in favor of self-termination of ventricular tachycardia/fibrillation. Am. J. Physiol. Heart. Circ. Physiol. 294, H1896-1905.

Harris, A.L., 2001. Emerging issues of connexin channels: biophysics fills the gap. Q. Rev. Biophys. 34, 325-472. 
Hoshino K, Ogawa K, Hishitani T, Isobe T, Etoh Y., 2006. Successful uses of magnesium sulfate for torsades de pointes in children with long QT syndrome. Pediatr Int. 48, 112-7.

Ishihara, K., Sarai, N., Asakura, K., Noma, A., Matsuoka, S. 2009. Role of $\mathrm{Mg}^{2+}$ block of the inward rectifier $\mathrm{K}^{+}$current in cardiac repolarization reserve: $\mathrm{A}$ quantitative simulation. J. Mol. Cell. Cardiol. 47, 76-84.

Kameyama, M., 1983. Electrical coupling between ventricular paired cells isolated from guinea-pig heart. J. Physiol. 336, 345-57.

Kasaoka S, Tsuruta R, Nakashima K, Soejima Y, Miura T, Sadamitsu D, Tateishi A, Maekawa T., 1996. Effect of intravenous magnesium sulfate on cardiac arrhythmias in critically ill patients with low serum ionized magnesium. Jpn Circ J. 60, 871-5.

Kuzumoto, M., Takeuchi, A., Nakai, H., Oka, C., Noma, A., Matsuoka, S., 2008. Simulation analysis of intracellular $\mathrm{Na}^{+}$and $\mathrm{Cl}^{-}$homeostasis during 81 -adrenergic stimulation of cardiac myocyte. Prog. Biophys. Mol. Biol. 96, 171-86.

Lurtz, M.M., Louis, C.F., 2007. Intracellular calcium regulation of connexin43. Am. J. Physiol. Cell Physiol. 293, C1806-13.

Michailova, A., McCulloch, A., 2001. Model study of ATP and ADP buffering, transport of $\mathrm{Ca}(2+)$ and $\mathrm{Mg}(2+)$, and regulation of ion pumps in ventricular myocyte. Biophysical Journal. 81, 614-29.

Mitra, R., Morad, M., 1985. A uniform enzymatic method for dissociation of myocytes from hearts and stomachs of vertebrates. Am. J. Physiol. 249, H1056-60.

Mubagwa, K., Gwanyanya, A., Zakharov, S., Macianskiene, R., 2007. Regulation of cation channels in cardiac and smooth muscle cells by intracellular magnesium. Arch Biochem Biophys. 2007. 458, 73-89. 
Murphy, E., Steenbergen, C., Levy, L.A., Raju, B., London, R.E., 1989. Cytosolic free magnesium levels in ischemic rat heart. J. Biol. Chem. 264, 5622-7.

Musso, C.G., 2009. Magnesium metabolism in health and disease. Int Urol Nephrol. 41, 357-362.

Noma, A., Tsuboi, N., 1987. Dependence of junctional conductance of proton, calcium and magnesium ions in cardiac paired cells of guinea-pig. J. Physiol. 382, 193-211.

Oka, C., Matsuda, H., Sarai, N., Noma, A., 2006. Modelling the calcium gate of cardiac gap junction channel. J. Physiol. Sci. 56, 79-85.

Oliveira-Castro, G.M., Loewenstein, W.R., 1971. Junctional membrane permeability. Effects of divalent cations. J. Membrane. Biol. 5, 51-77.

Onalan O, Crystal E, Daoulah A, Lau C, Crystal A, Lashevsky I., 2007. Meta-analysis of magnesium therapy for the acute management of rapid atrial fibrillation. Am J Cardiol. 99, 1726-32.

Peracchia, C., 2004. Chemical gating of gap junction channels roles of calcium, PH and calmodulin. Biochimica. Biophysica. Acta.1662, 61-80.

Rossi S, Baruffi S, Bertuzzi A, Miragoli M, Corradi D, Maestri R, Alinovi R, Mutti A, Musso E, Sgoifo A, Brisinda D, Fenici R, Macchi E. 2008. Ventricular activation is impaired in aged rat hearts. Am. J. Physiol. Heart. Circ. Physiol. 295, H2336-47.

Shi, J., Krishnamoorthy, G., Yang, Y., Hu, L., Chaturvedi, N., Harilal, D., Qin, J., Cui, J., 2002. Mechanism of magnesium activation of calcium-activated potassium channels. Nature. 418, 876-80.

Sugiura, H., Toyama, J., Tsuboi, N., Kamiya, K., Kodama, I., 1990. ATP directly affects junctional conductance between paired ventricular myocytes isolated from guinea pig heart. Circ. Res. 66, 1095-102. 
Swietach, P., Rossini, A., Spitzer, K.W., Vaughan-Jones, R.D., 2007. H+ ion activation and inactivation of the ventricular gap junction: a basis for spatial regulation of intracellular pH. Circ. Res. 100, 1045-54.

Toyama, J., Sugiura, H., Kamiya, K., Kodama, I., Terasawa, M., Hidaka, H., 1994. $\mathrm{Ca} 2+$-calmodulin mediated modulation of the electrical coupling of ventricular myocytes isolated from guinea pig heart. J. Mol. Cell. Cardiol. 26, 1007-15.

Veenstra, R.D., Dehaan, R.L., 1988. Cardiac gap junction channel activity in embryonic chick ventricle cells. Am. J. Physiol. 254, H170-80.

Vemana, S., Pandey, S., Larsson, H.P., 2008. Intracellular $\mathrm{Mg}^{2+}$ is a voltage-dependent pore blocker of HCN channels. Am. J. Physiol. Cell Physiol. 295, C557-65.

Wang, M., Berlin, J.R., 2006. Channel phosphorylation and modulation of L-type $\mathrm{Ca}^{2+}$ currents by cytosolic $\mathrm{Mg}^{2+}$ concentration. Am. J. Physiol. Cell Physiol. 291, C83-92.

\section{FIGURES' LEGEND}

Fig.1. Electrophysiological recording of gap junction channel conductance

A. Diagram of the experiment setup. B. Pulse protocol. The current response to \pm $5 \mathrm{mV}$ from a holding potential of $0 \mathrm{mV}$ was recorded every $500 \mathrm{~ms}$. C. Equivalent circuits before and after laser perforation. ELv: electrode for voltage recording, ELI: electrode for current feeding, $\mathrm{Gj}$ : gap junction channels conductance, $\mathrm{G}_{\mathrm{m}, 1}$ : non-junctional membrane conductance of cell $1, \mathrm{G}_{\mathrm{m}, 2}$ : non-junctional membrane conductance of cell 2, Gs: conductance through the holes made in cell 2.

Fig.2. Time course of $\mathrm{G}_{\mathrm{j}}$ change

A. Representative current records. B. Time course of $\mathrm{G}_{\mathrm{j}}$ change. a; before perforation, b; immediately after perforation, c; steady-state at $10 \mathrm{mM} \mathrm{d}$; $\mathrm{Mg}^{2+}$,steady state at $0.1 \mathrm{mM} \mathrm{Mg}{ }^{2+} . \mathrm{Mg}^{2+}$ concentrations are denoted above the graph. 
Fig.3. Comparison of time course of $\mathrm{G}_{\mathrm{j}}$ decay at three different distances between the junction and holes. The myocytes were superfused with a solution containing $10 \mathrm{mM} \mathrm{Mg}^{2+}$. $\mathrm{G}_{\mathrm{j}}$ was normalized to the one immediately after the laser perforation.

Fig.4. Kinetics of $\mathrm{Mg}^{2+}$ gate of GJCs.

Single exponential fit of $\mathrm{G}_{\mathrm{j}}$ modulation $\mathrm{Mg}^{2+}$. Data (black circles, A; $10 \mathrm{mM} \mathrm{Mg}^{2+}$, B: $0.6 \mathrm{mM} \mathrm{Mg}^{2+}$ ) are fitted with single exponential function (gray circles). Relationships between $\left[\mathrm{Mg}^{2+}\right]_{\mathrm{i}}$ and $\tau^{-1}(\mathrm{D})$ and between $\left[\mathrm{Mg}^{2+}\right]_{\mathrm{i}}$ and $\mathrm{G}_{\mathrm{j}}(\mathrm{C})$. In $\mathrm{C}$, the data were normalized to the value at $0.1 \mathrm{mM}\left[\mathrm{Mg}^{2+}\right]_{\mathrm{i}}$. The data numbers were three at 3 and $10 \mathrm{mM}\left[\mathrm{Mg}^{2+}\right]_{\mathrm{i}}$ in $(\mathrm{C})$, and two at $3 \mathrm{mM}\left[\mathrm{Mg}^{2+}\right]_{\mathrm{i}}$ and four at 10 $\mathrm{mM}\left[\mathrm{Mg}^{2+}\right]_{\mathrm{i}}$, respectively. Others are one. Gray lines are least square fit. In B, the equation is $\mathrm{y}=\mathrm{y} 0+\mathrm{a}^{*} \mathrm{c}^{\mathrm{b}} /\left(\mathrm{c}^{\mathrm{b}}+\left[\mathrm{Mg}^{2+}\right] \mathrm{b}\right)$, with $\mathrm{a}=0.957, \mathrm{~b}=3.4, \mathrm{c}=0.6, \mathrm{y} 0=0.0217$. $\mathrm{G}_{\mathrm{j}}$ was normalized to the one at $0.1 \mathrm{mM} \mathrm{Mg}^{2+}$.

Fig.5. Schemes of Mg gate model. A. Two-state model. B. Four-state model.

Fig.6. Simulation results.

A. A relationship between $\left[\mathrm{Mg}^{2+}\right]_{\mathrm{i}}$ and $\mathrm{G}_{\mathrm{j}}$. B. A relationship between $\left[\mathrm{Mg}^{2+}\right]_{\mathrm{i}}$ and $\tau^{-1}$. Black circles are experimental data (same as in fig. $4 \mathrm{C}$ ) and gray circles are model simulation. C. and D. Time course. Experimental data (black circles; same as fig. 4D) were $\mathrm{Gj}$ normalized to the one at $0.1 \mathrm{mM} \mathrm{Mg}^{2+}$ and open probability was plotted for model simulation (gray circles).

Fig.7. Action potential propagation in the $1-\mathrm{D}$ cable model at various $\left[\mathrm{Mg}^{2+}\right]_{\mathrm{i}}$. A. Diagram of 1-D cable model. B. Relationship between $\left[\mathrm{Mg}^{2+}\right]_{\mathrm{i}}$ and conduction velocity (CV) in the $1-\mathrm{D}$ cable model. $\mathrm{CV}$ was calculated at cell 15 . C. Action potentials of 30 cells at three different $\left[\mathrm{Mg}^{2+}\right]_{\mathrm{i}} ; 0.1$ (left), 0.7 (middle), 2.0 (right) $\mathrm{mM}$.

Fig. 8. Time course of gap junction modulation by $\mathrm{Mg}^{2+}$. A. Open probability. $\left[\mathrm{Mg}^{2+}\right]_{\mathrm{i}}$ of cell $11^{-30}$ was increased to $2.6 \mathrm{mM}$ at time of $4.0 \mathrm{sec}$. B. Action potentials of the 30 cells $76 \mathrm{sec}$ after the $\left[\mathrm{Mg}^{2+}\right]_{\mathrm{i}}$ increase. 
Fig.1

A

B
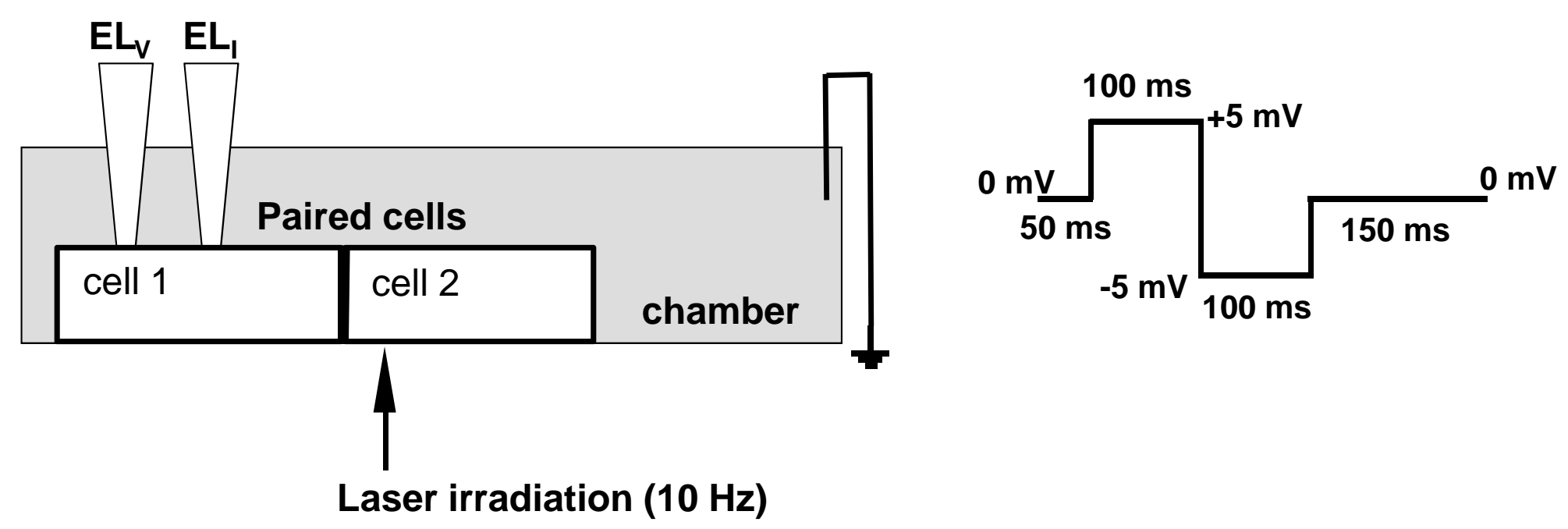

C
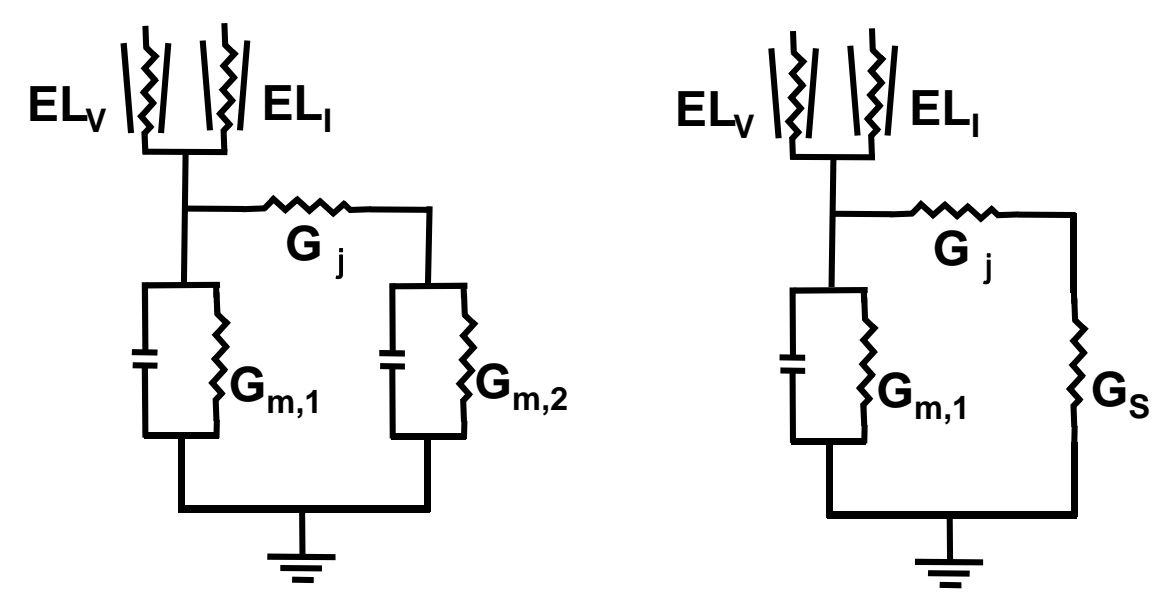

Before the perforation

After the perforation 
Fig.2

A

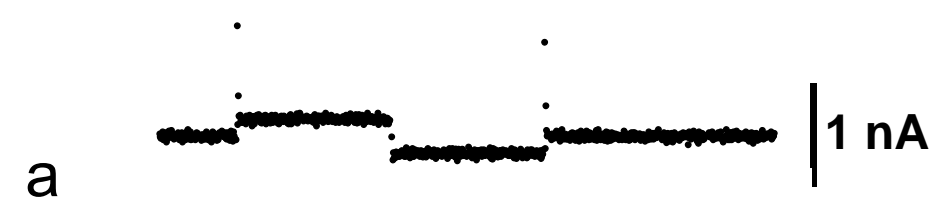

C

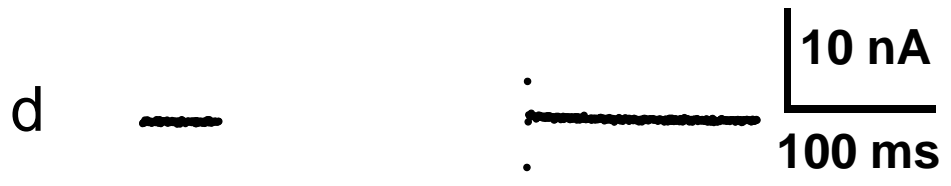

B

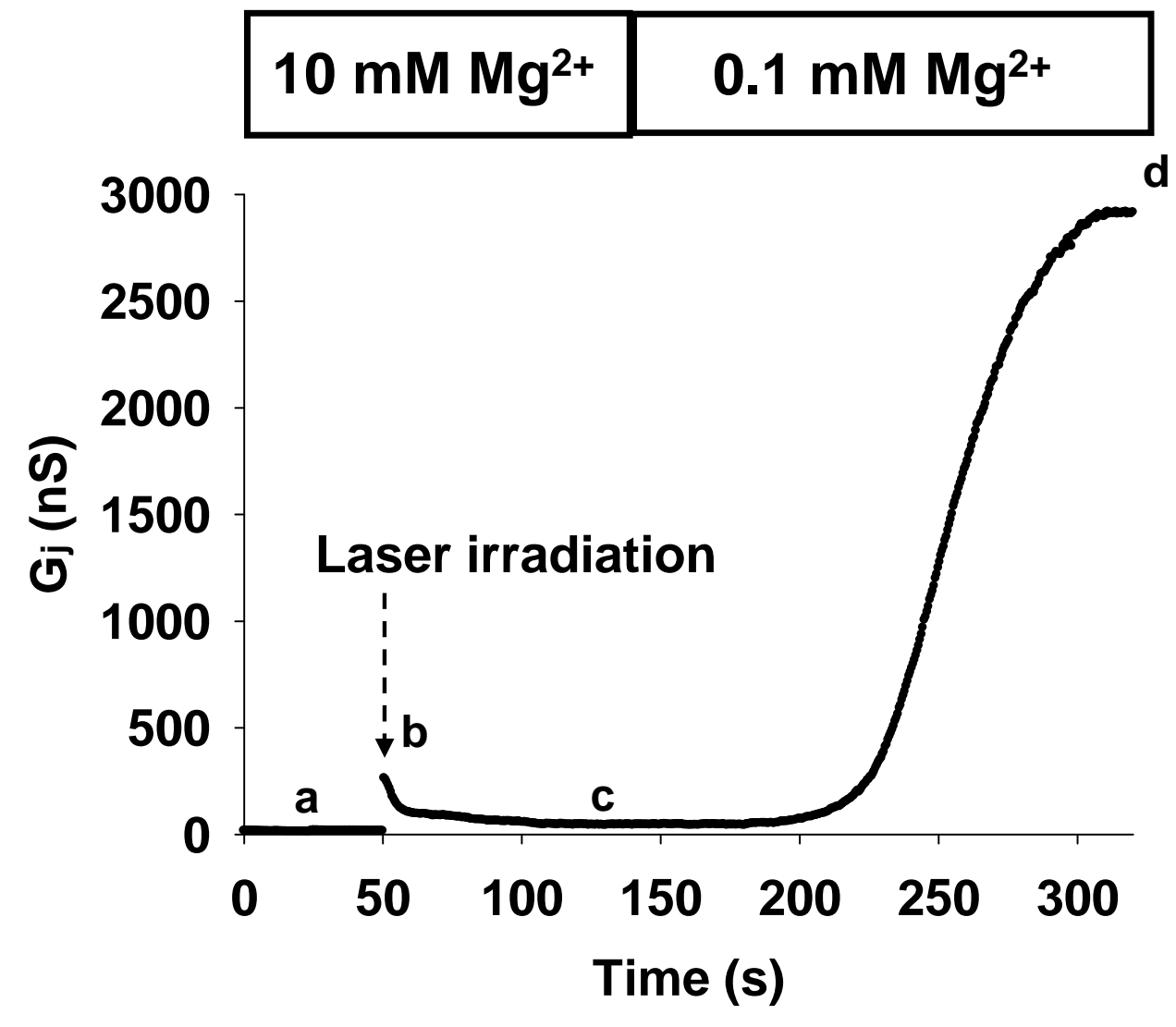


Fig.3

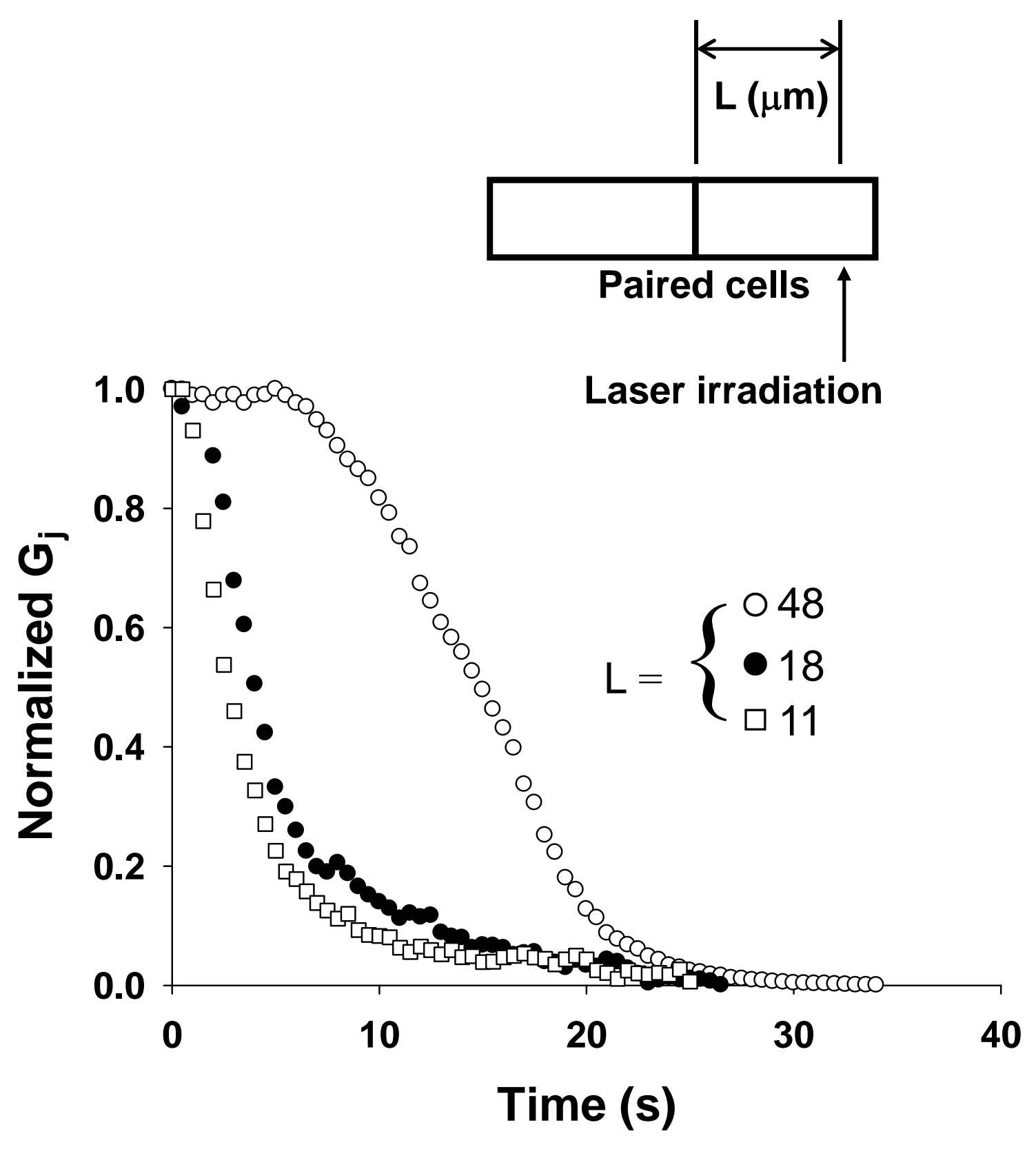


Fig.4
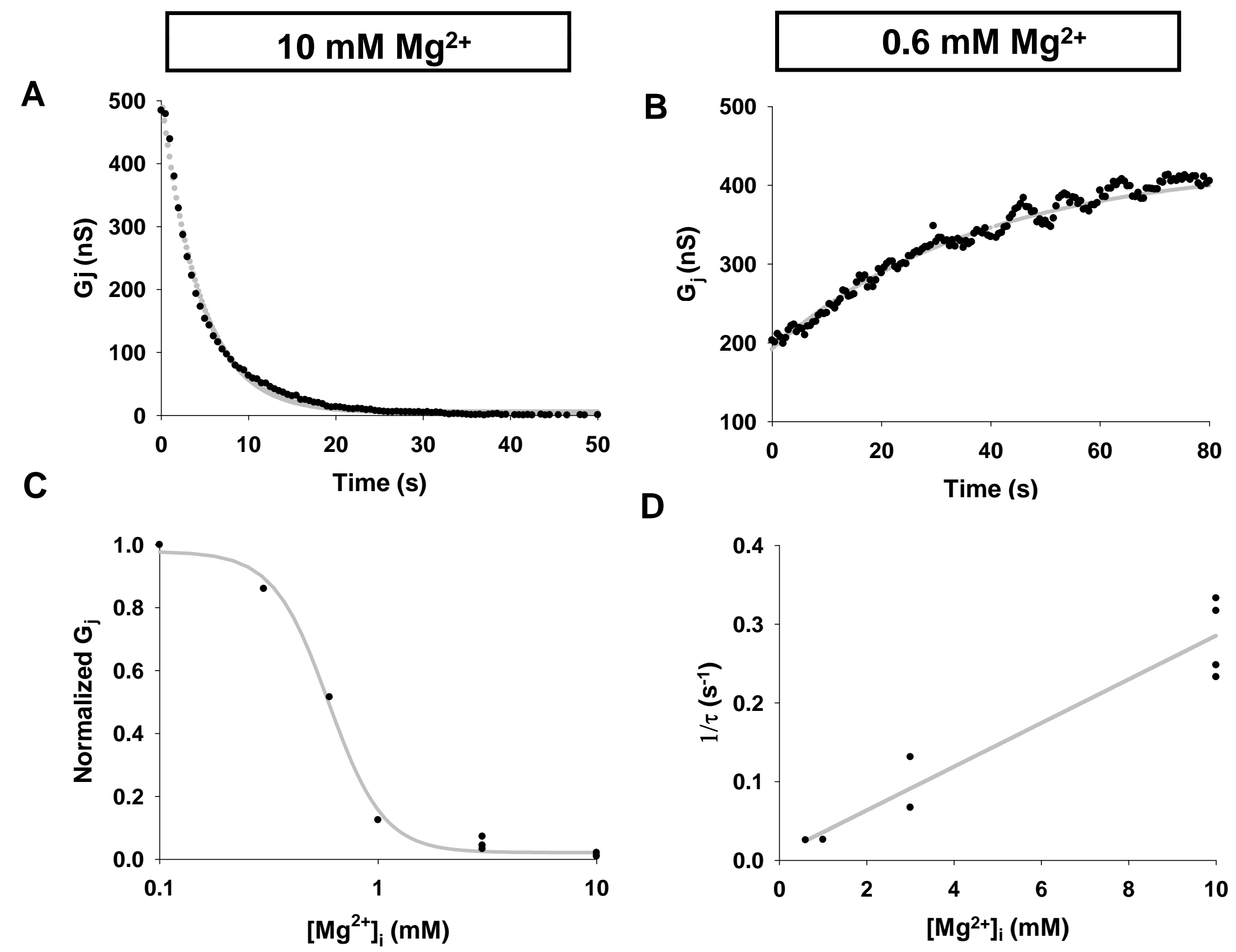
Fig.5

A: simple two state model

$$
\mathrm{O} \underset{\beta}{\stackrel{M^{2+}}{\rightleftarrows}} \mathrm{C}
$$

B-1: RLS in $1^{\text {st }}$ step

B-2: RLS in $2^{\text {nd }}$ step

$$
\begin{aligned}
& \mathrm{Mg}^{2+} \mathrm{Mg}^{2+} \mathrm{Mg}^{2+} \\
& \mathbf{O} \underset{\beta}{\stackrel{\alpha_{1}}{\rightleftarrows}}\left(\mathbf{C} \underset{\beta_{2}}{\stackrel{\alpha_{2}}{\rightleftarrows}} \mathbf{C} \underset{\beta_{3}}{\stackrel{\alpha_{3}}{\longrightarrow}} \mathbf{C}\right) \\
& \mathrm{Mg}^{2+} \mathrm{Mg}^{2+} \mathrm{Mg}^{2+} \\
& \left(\mathbf{O} \underset{\beta_{1}}{\stackrel{\alpha_{1}}{\rightleftarrows}} \mathbf{O}\right) \underset{\beta_{2}}{\stackrel{\alpha_{2}}{\rightleftarrows}}\left(\mathbf{C} \underset{\beta_{3}}{\stackrel{\alpha_{3}}{\longrightarrow}} \mathbf{C}\right)
\end{aligned}
$$

$\mathrm{Mg}^{2+} \mathrm{Mg}^{2+} \mathrm{Mg}^{2+}$

B-3: RLS in $3^{\text {rd }}$ step

$$
\left(\mathbf{O} \underset{\beta_{1}}{\stackrel{\alpha_{1}}{\longrightarrow}} \mathrm{O} \underset{\beta_{2}}{\stackrel{\searrow \alpha_{2}}{\rightleftarrows}} \mathrm{O}\right) \underset{\beta_{3}}{\stackrel{\alpha_{3}}{\rightleftarrows}} \mathbf{C}
$$


Fig.6
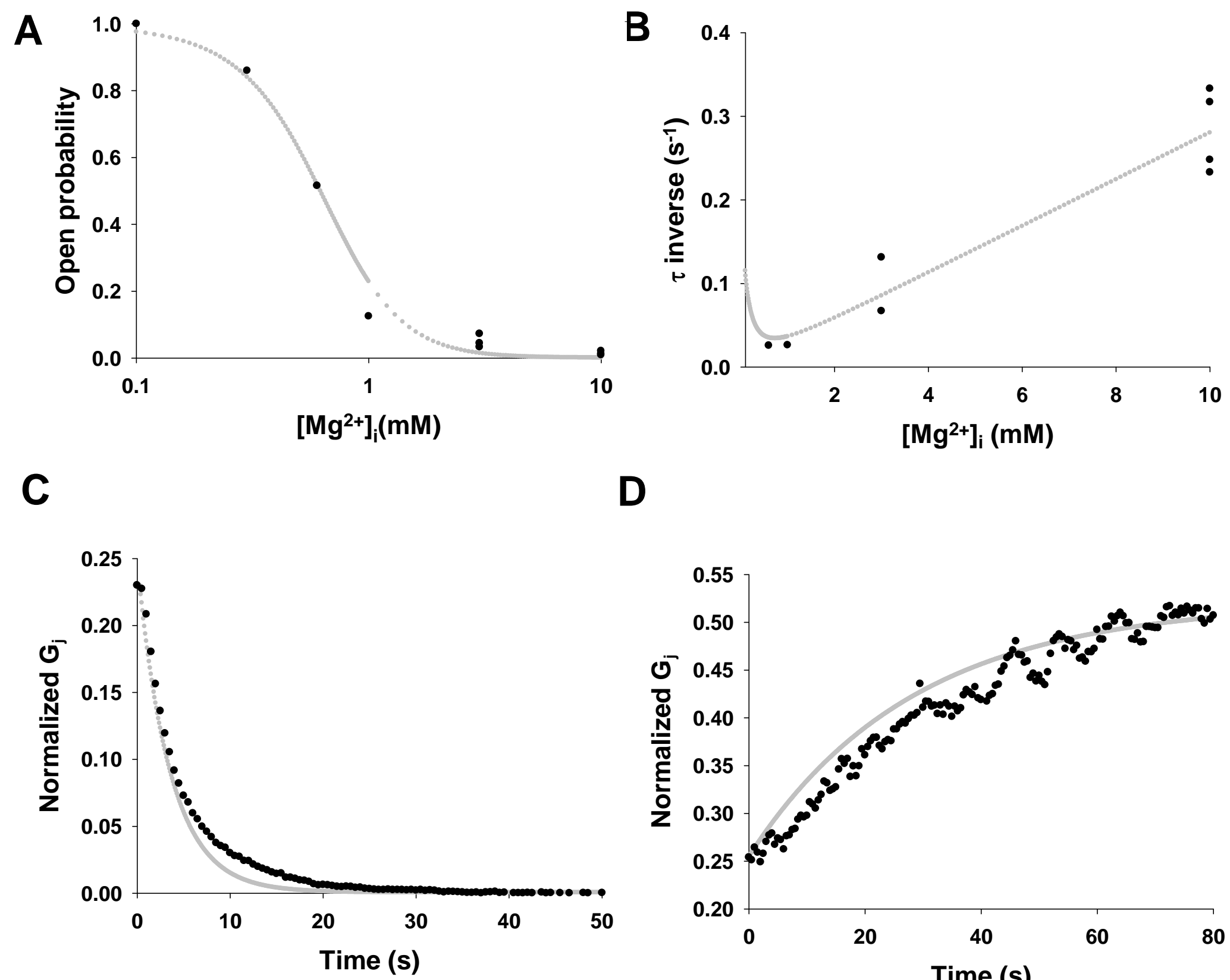

D

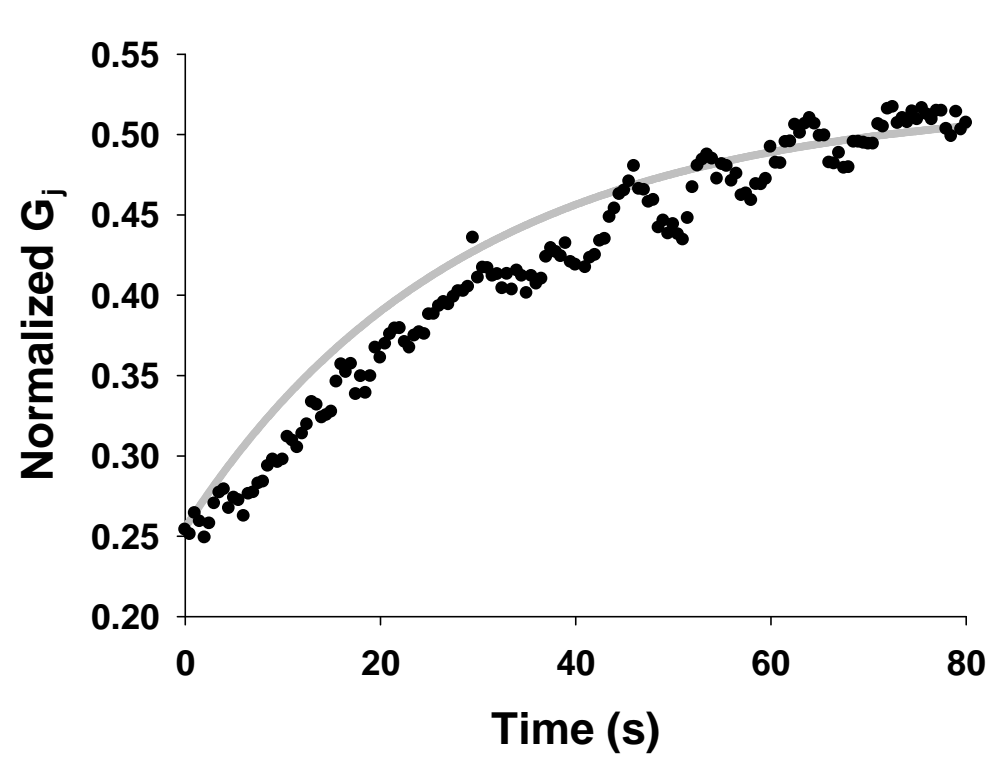


Fig.7
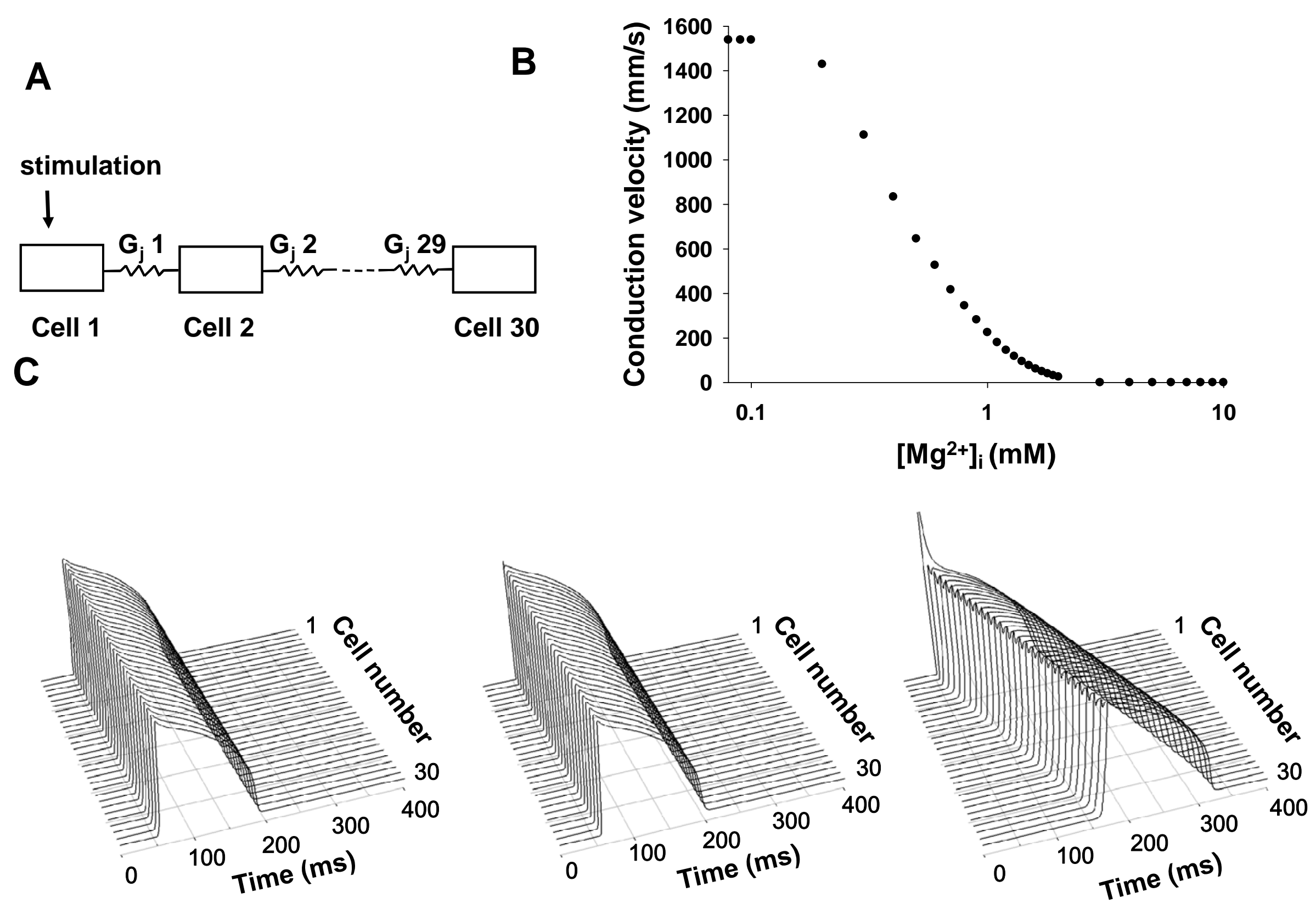
Fig.8

A

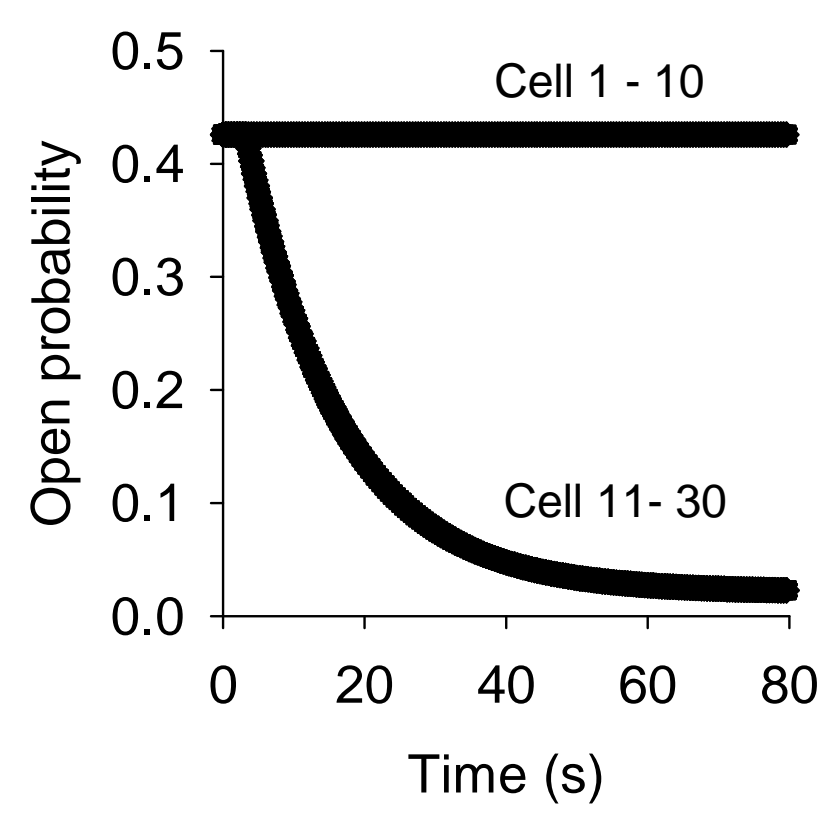

B

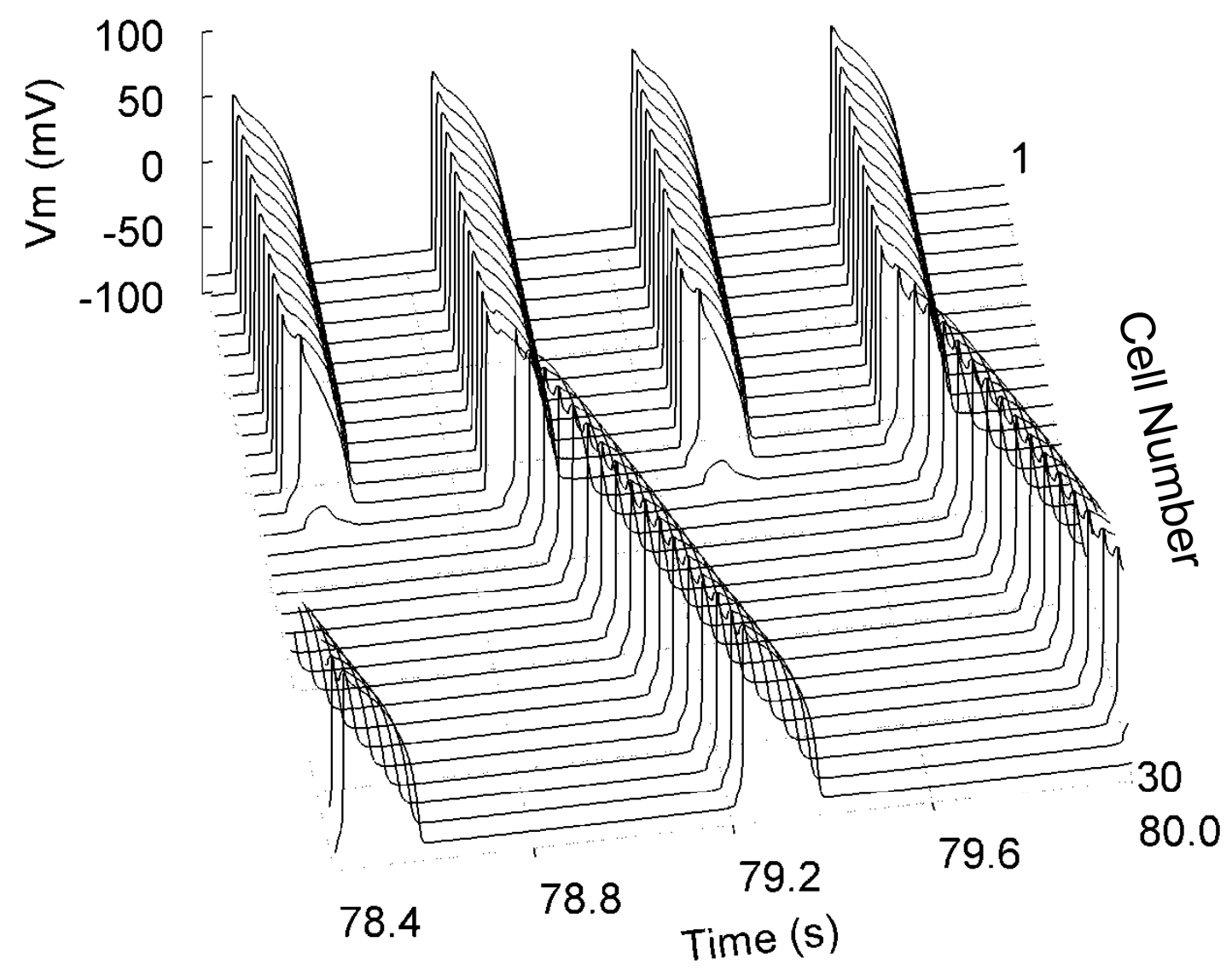

